\title{
Advantages and disadvantages of ceramic on ceramic total hip arthroplasty: A review
}

\author{
Jiri Gallo ${ }^{a}$, Stuart Barry Goodman ${ }^{b}$, Jiri Lostak ${ }^{a}$, Martin Janout ${ }^{\mathrm{a}}$
}

\begin{abstract}
Background. Ceramic on ceramic (COC) total hip arthroplasty (THA) was developed to reduce wear debris and accordingly, the occurrence of osteolysis and aseptic loosening especially in younger patients. Based on the excellent tribological behavior of current $\mathrm{COC}$ bearings and the relatively low biological activity of ceramic particles, significant improvement in survivorship of these implants is expected.

Methods. We used manual search to identify all relevant studies reporting clinical data on COC THAs in PubMed. The objective was to determine whether current COC THA offers a better clinical outcome and survivorship than non-COC THA.

Results. Studies with early generation ceramic bearings yielded $68 \%$ to $84 \%$ mean survivorship at 20 years follow-up which is comparable with the survivorship of non-COC THAs. Studies on current ceramic bearings report a 10-year revision-free interval of $92 \%$ to $99 \%$. These outcomes are comparable to the survivorship of the best non-COC THAs. However, there are still concerns regarding fracture of sandwich ceramic liners, squeaking, and impingement of the femoral neck on the rim of the ceramic liner leading to chipping, especially in younger and physically active patients. Conclusion. Current COC THA leads to equivalent but not improved survivorship at 10 years follow-up in comparison to the best non-COC THA. Based on this review, we recommend that surgeons weigh the potential advantages and disadvantages of current COC THA in comparison to other bearing surfaces when considering young very active patients who are candidates for THA.
\end{abstract}

Key words: total hip arthroplasty, ceramic on ceramic, revision free interval, survivorship, advantages, disadvantages, osteolysis, aseptic loosening

Received: November 22, 2011; Accepted: June 13, 2012; Available online: September 30, 2012

http://dx.doi.org/10.5507/bp.2012.063

${ }^{a}$ Department of Orthopaedics, Faculty of Medicine and Dentistry, Palacky University Olomouc and University Hospital Olomouc, Czech Republic

${ }^{b}$ Department of Orthopaedic Surgery, Stanford University Medical Center Outpatient Center, 450 Broadway St., M/C 6342, Redwood City, CA, USA, 94063

Corresponding author: Jiri Gallo, email:jiri.gallo@volny.cz

\section{INTRODUCTION}

Particle-induced periprosthetic osteolysis and aseptic loosening are major complications of total hip arthroplasty (THA). The current paradigm relates osteolysis and loosening of THA to the cellular host adverse reaction due to continuous particle delivery from artificial joint surfaces ${ }^{1}$. As osteolysis is closely associated with the production of large quantities of polyethylene (PE) particles, one solution would be to exclude PE from bearing materials used in THA and replace it by much harder and wear-resistant materials. The history of the use of ceramic materials, their structures, and the clinical outcomes of THAs with ceramic-on-ceramic (COC) bearings are described in detail elsewhere ${ }^{2}$.

Here, we focus on the current ceramic materials that are used in orthopaedic practice today. These are formed by fusion of microscopic grains of alumina $\left(\mathrm{Al}_{2} \mathrm{O}_{3}\right)$ and/ or zirconia $\left(\mathrm{ZrO}_{2}\right)$ ceramic powder into a solid phase (Table 1). The process of sintering is "hot isostatic pressing” requiring temperatures exceeding $1400{ }^{\circ} \mathrm{C}$ and pressures above 1000 Bars. After sintering, the components are ground and polished to get the finest surface possible. The manufacturing of COC bearings for orthopaedics is under strict control (more than 50 checkpoints according to the declaration of CeramTech AG, Plochingen, Germany) and in accordance with international quality standards (ISO 6474).

Compared to other currently used bearing couples, modern COC bearings demonstrate the lowest wear rates both in vitro and in vivo. For this reason, excellent clinical performance can be expected. The aim of this paper is to review the advantages and disadvantages associated with current COC THA.

\section{LITERATURE SEARCH}

PubMed (1996-2011) was meticulously searched to detect studies reporting clinical outcomes for COC THA using the following keywords and their combinations: "total hip arthroplasty/replacement", "ceramic", "ceramic on ceramic", "aseptic loosening”, "osteolysis”, and "complications". The relevant data including ceramic material, 
Table 1. Characteristics of ceramic materials used currently in total hip arthroplasty.

\begin{tabular}{lcccccc}
\hline Type of ceramic & $\begin{array}{c}\text { Grain size } \\
(\mu \mathrm{m})\end{array}$ & $\begin{array}{c}\text { Density } \\
\left(\mathrm{g} / \mathrm{m}^{3}\right)\end{array}$ & $\begin{array}{c}\text { Bending } \\
\text { strength } \\
(\mathrm{MPa})\end{array}$ & $\begin{array}{c}\text { Fracture } \\
\text { toughness } \\
\left(\mathrm{MPa} \cdot \mathrm{m}^{1 / 2}\right)\end{array}$ & $\begin{array}{c}\text { Vickers } \\
\text { hardness }\end{array}$ & $\begin{array}{c}\text { Young's } \\
\text { modulus } \\
(\mathrm{GPa})\end{array}$ \\
\hline Alumina (BIOLOX FORTE) & $<2$ & 3.98 & 580 & 4 & 20 & 380 \\
Zirconia & $<0.5$ & n.a. & $>900$ & 8 & 12.5 & 210 \\
ZTAMC (BIOLOX DELTA) & $<2$ & 4.37 & $>1380$ & 6.5 & 19 & $>350$ \\
\hline
\end{tabular}

ZTAMC - Zirconia-toughened alumina matrix composite; n.a.-not available. Sources: CeramTec AG, Plochingen, Germany

number of patients/hips, period of implantation, primary diagnosis, average age at the time of surgery, sex, mean follow-up, survivorship, revision rate and reasons for revision were extracted. In addition, the best available data for non-COC THA were searched for the same period using identical search strategy except the word "ceramic". Finally, literature pertinent to material characteristics of COC THA was searched using Google.

\section{ADVANTAGES OF CERAMIC-ON-CERAMIC THA}

\section{Tribological remarks}

Current ceramics used for manufacturing bearing surfaces in THA exhibit outstanding tribological properties, the most important of which are hardness and high degree of wetability. Ceramic has a greater hardness than metal and can be polished to a much lower surface roughness while excellent wetability ensures that the synovial fluid is uniformly distributed between implant surfaces ${ }^{3}$. The former guarantees high resistance to major scratches and undetectable wear rate, while the latter facilitates fluid-film lubrication thus contributing to very low friction between articulating surfaces $\left(<1.7 \times 10^{-7} \mathrm{~mm}^{3} / \mathrm{Nm}\right)\left(\right.$ ref. $\left.^{4}\right)$.

The basic mechanism of wear in COC articulations is intergranular erosion followed by isolated grain pull-out ${ }^{3}$. In fact, hip simulator studies of current COC bearings have shown very low wear rates (less than $0.1 \mathrm{~mm}^{3}$ per million cycles) (ref. ${ }^{5}$ ). However, measurement of retrieved ceramic implants revealed much higher wear rates than above ( $\geq 1 \mathrm{~mm}^{3} / \mathrm{yr}$.) and a characteristic "ceramic" wear pattern was noted ${ }^{6-8}$. The reason for these differences could lie in different biomechanical conditions in vitro and in vivo, with the latter being exposed to edge loading, recurrent separation of bearing surfaces and even direct impingement of the ceramic implant on the neck of the stem, that increase the total wear of the implant in vivo. However, even under microseparation conditions, the wear rates of current alumina and ZTAMC ceramics are lower than highly cross-linked polyethylene (up to 1.8 $\mathrm{mm}^{3} /$ million cycles) (ref. ${ }^{7}$ ).

\section{Size of ceramic particles}

Ceramic wear particles are continually released into the effective joint space during each step similar to non-
COC THA. Depending on the mechanism of wear, ceramic particles are typically generated in smaller numbers and with a bimodal size range involving nanometer size particles (mean $24 \mathrm{~nm}$; range 5 to $90 \mathrm{~nm}$ ) and larger particles (mean $0.43 \mu \mathrm{m}$; range 0.05 to $3.2 \mu \mathrm{m}$ ) probably associated with grain boundary fracture ${ }^{9-10}$. In addition, even larger ceramic particles are generated during gross damage (catastrophic failure) of the bearing surfaces (Fig. 1).
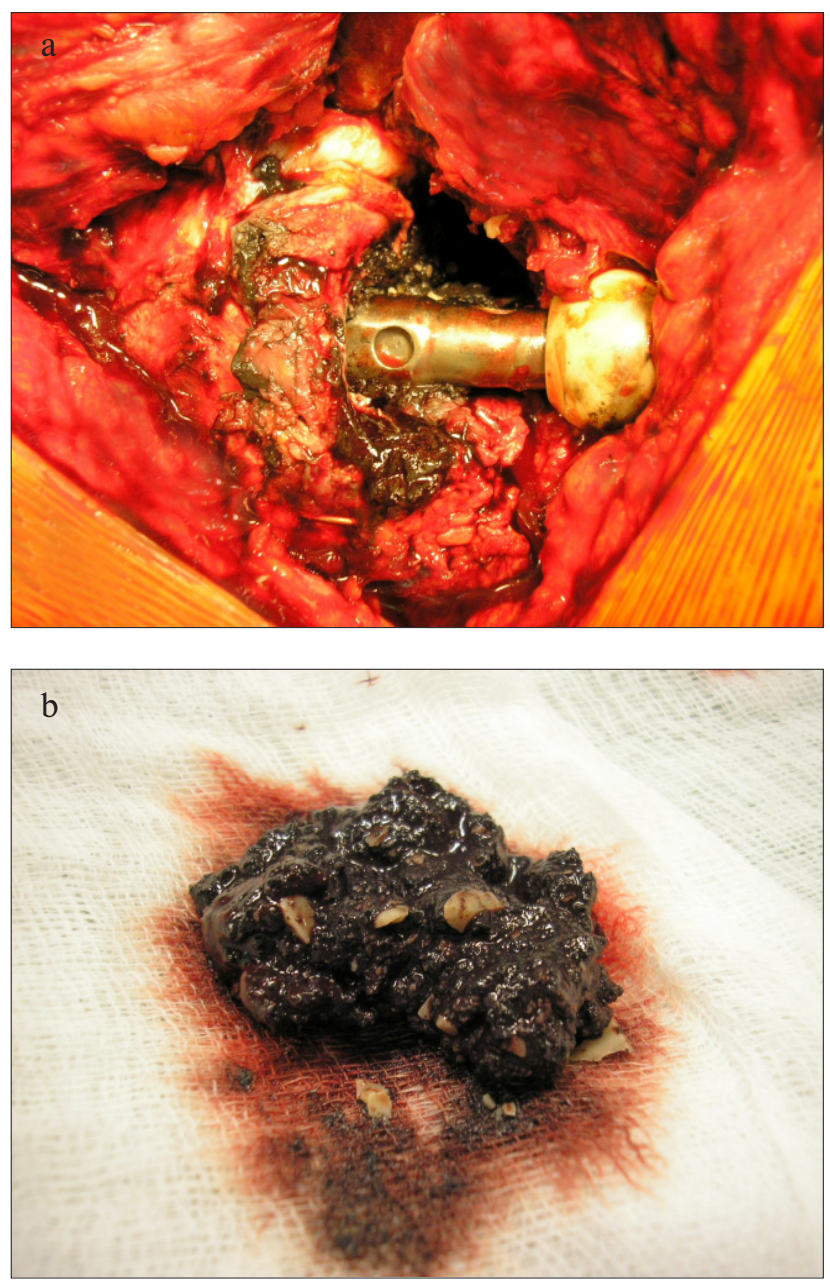

Fig. 1. Left hip revised due to catastrophic failure of ceramic liner (a); metallosis with gross fragments of broken ceramic liner (b). 


\section{Biological activity of ceramic particles}

Prosthetic particles released from artificial joints stimulate periprosthetic cells to produce an inflammatory and pro-osteolytic environment leading eventually to alteration of local bone homeostasis in favour of bone resorption. Generally, the impact of particle load on the extension of bone defects depends at least on the size, amount, origin, and shape of the particles ${ }^{11}$.

COC THAs exhibit very low ceramic wear rates and in addition, ceramic wear particles have much lower specific and functional biological activity than polyethylene particles $^{12-13}$. Catelas et al. showed that polyethylene particles stimulated greater release of TNF- $\alpha$ when compared to alumina or zirconia ${ }^{14}$. Kubo et al. found much less intense histiocytic response around particles of alumina ceramics (3.9 $\mu \mathrm{m}$ in diameter) than that of UHMWPE $(11 \mu \mathrm{m})$, stainless steel $(3.9 \mu \mathrm{m})$, and $\mathrm{CoCr}(3.9 \mu \mathrm{m})$ in a rabbit mode ${ }^{15}$. Bos et al. studied macrophages in the pseudo- synovial membrane from well-fixated implants retrieved at autopsy and found the percentage of macrophages was higher in the polyethylene-on-ceramic and metal-on-polyethylene groups (40-60\%) than in the ceramic-on-ceramic group (20-40\%) (ref. ${ }^{16-17}$ ). On the other hand, at least one study comparing macrophage apoptosis as a result of stimulation by alumina, zirconia, and PE particles found the response to be size and concentration dependent, rather than particle composition dependent ${ }^{18}$. The overall impression is that ceramic particles are biologically inert, but if released in sufficient numbers (e.g. cases of neck impingement or third body wear), ceramic particles can produce osteolysis similar to that induced by PE particles. In comparable doses, however, the biologic response is less intense with ceramic versus PE particles.

From the above, it could be deduced that osteolysis and aseptic loosening will be obviated in patients with COC THA. Unfortunately, this is controversial because

Table 2. List of the selective studies reporting survivorship for COC and non-COC THAs; unfortunately the majority of retrieved studies have several inconsistencies in reporting (e.g. unclear number of patients and hips, survivorship without the Kaplan-Maier statistical analysis, unreported 95\% confidence interval) precluding direct comparison in above terms.

\begin{tabular}{|c|c|c|c|c|c|c|c|c|c|}
\hline Author & $\begin{array}{c}\text { Bearing } \\
\text { pair }\end{array}$ & $\begin{array}{c}\text { Number of } \\
\text { patients }\end{array}$ & $\begin{array}{l}\text { Number } \\
\text { of THAs }\end{array}$ & $\begin{array}{c}\text { Period of } \\
\text { implantation }\end{array}$ & $\begin{array}{c}\text { Average } \\
\text { age } \\
\text { (yrs.) }\end{array}$ & $\begin{array}{l}\text { Range } \\
\text { from to } \\
\text { (yrs.) }\end{array}$ & $\begin{array}{l}\text { Follow- } \\
\text { up term }\end{array}$ & $\begin{array}{c}\text { Survivorship } \\
\text { (\%) }\end{array}$ & $\begin{array}{c}95 \% \text { CI } \\
\text { (confidence } \\
\text { interval) }\end{array}$ \\
\hline Milosev et al. ${ }^{48}$ & M-M & 591 & 640 & 1994-2002 & 57 & $18-80$ & 10 & 91 & $88-95$ \\
\hline Neumann et al..$^{49}$ & M-M & 99 & 100 & 1995-1996 & 56.7 & $36-75$ & 10 & 94 & $89-99$ \\
\hline Migaud et al. ${ }^{50}$ & M-M & 30 & 39 & 1995-1998 & 39.8 & $23-49$ & 12 & 100 & NA \\
\hline Neuerburg et al. ${ }^{51}$ & M-M & 1121 & 1270 & NA & NA & NA & 10 & 90 & $86-94$ \\
\hline Delaunay et al. ${ }^{52}$ & M-M & 73 & 83 & 1995-2004 & 40.7 & $23-49$ & 10 & 100 & $89.6-100$ \\
\hline Kim et al. ${ }^{53}$ & C-HPE & 71 & 73 & 2000-2002 & 45.5 & $20-50$ & 8.5 & 100 & $98-100$ \\
\hline Garavaglia et al. ${ }^{54}$ & C-HPE & 518 & 561 & 1996-1998 & 69.3 & $24-98$ & 10 & $98.8^{*}$ & $97.4-99.5^{*}$ \\
\hline Grobler et al. ${ }^{55}$ & M-HPE & 93 & 100 & 1991-1993 & 54 & $24-71$ & 10 & 100 & NA \\
\hline Zweymüller et al. ${ }^{56}$ & C-P & 365 & 376 & 1993-1994 & 62.8 & $20-83$ & 10 & 99.3 & 96.9-99.8 \\
\hline Epinette et al. ${ }^{57}$ & C-P & 384 & 418 & 1989-1991 & 69.6 & $21-88$ & 10 & 98.2 & NA\# \\
\hline Kim et al. ${ }^{53}$ & C-P & 78 & 109 & 1991-1993 & 46.8 & $21-49$ & 10 & 93.6 & NA \\
\hline Wroblewski et al. ${ }^{58}$ & C-P & NA & 3611 & $1962-2005$ & 67 & $12-93$ & 10 & $97.5^{*}$ & $97.0-98.0 *$ \\
\hline Chevillotte et al. ${ }^{59}$ & $\mathrm{C}-\mathrm{C}$ & 92 & 100 & 1999-2000 & 52.3 & $20-73$ & 9 & 95.8 & NA \\
\hline Murphy et al. ${ }^{60}$ & $\mathrm{C}-\mathrm{C}$ & 173 & 194 & $1997-2003$ & 49.9 & $18-76$ & 9 & 96 & $91-100$ \\
\hline Park et al. ${ }^{61}$ & $\mathrm{C}-\mathrm{C}$ & 90 & 102 & 1999-2002 & 39 & $18-66$ & 9.6 & 95.3 & $89.5-100$ \\
\hline Mesko et al. ${ }^{62}$ & $\mathrm{C}-\mathrm{C}$ & 848 & 930 & $1996-2000$ & 51.3 & NA & 10 & 96.8 & $94.6-98.1$ \\
\hline Boyer et al. ${ }^{27}$ & $\mathrm{C}-\mathrm{C}$ & 76 & 83 & 1993-2003 & 39 & NA & 10 & 92 & NA\#\# \\
\hline Lee et al. ${ }^{28}$ & $\mathrm{C}-\mathrm{C}$ & 84 & 100 & NA & 41 & $18-65$ & 10 & 99 & $97-100$ \\
\hline D'Antonio et al. ${ }^{26}$ & $\mathrm{C}-\mathrm{C}$ & 189 & 216 & NA & 53.1 & $30-73$ & 10.3 & 97.9 & $91.9-99.5$ \\
\hline Kress et al. ${ }^{29}$ & $\mathrm{C}-\mathrm{C}$ & 71 & 75 & 1997-1999 & 58 & $34-77$ & 10.5 & 97 & NA \\
\hline Sugano et al. ${ }^{63}$ & C-C & 87 & 100 & 1996-1998 & 56 & $41-73$ & 14 & 95.7 & $89.0-98.4$ \\
\hline
\end{tabular}

NA - not available, M-M - metal-on-metal, C-HPE - ceramic-on-highly cross-linked polyethylene, M-HPE - metal-on-highly cross-linked polyethylene, C-P - ceramic-on-conventional polyethylene, C-C - ceramic-on-ceramic, \# - survivorship, calculated using revision for all causes at 10 years, was $98.24 \% \pm 0.0167$, \#\# - the 10 -year overall survival rate, considering failure to be revision for any cause, was $92 \pm 11 \%$, * survival analysis with revision for a loose acetabular component as the end-point 
Table 3. Summary for a review on ceramic on ceramic THA.

\begin{tabular}{lccc}
\hline Parameter & Ceramic on Ceramic & $\begin{array}{c}\text { Ceramic/Metal } \\
\text { on Polyethylene }\end{array}$ & Metal on Metal \\
\hline Wear rate & $30.5 \pm 7 \mu \mathrm{m} / \mathrm{y}^{64}$ & $218.2 \pm 13.7 \mu \mathrm{m} / \mathrm{y}^{64}$ & $20-25 \mu \mathrm{m} / \mathrm{y}^{65}$ \\
Particle size & $0.13-78 \mu \mathrm{m}^{66}$ & $30 \mathrm{~nm}-10 \mu \mathrm{m}^{67}$ & $30-100 \mathrm{~nm}^{68}$ \\
$\begin{array}{l}\text { Cellular response to wear } \\
\text { particles }\end{array}$ & Low & High & High \\
$\begin{array}{l}\text { Hypersensitivity induced } \\
\text { by wear debris }\end{array}$ & No & No & Yes \\
Tissue necrosis, ALVAL & No or weak & Weak & High grade \\
Dislocation\# & $0.78 \%$ & $0.80 \%$ & $0.74 \%$ \\
Infection\# & $0.32 \%$ & $0.49 \%$ & $0.53 \%$ \\
Mechanical loosening\# & $0.39 \%$ & $0.22 \%$ & $0.20 \%$ \\
Revision\# & $1.02 \%$ & $1.16 \%$ & $1.12 \%$ \\
Noisy hip & Up to $33 \%$ & Rarely & Less frequent \\
Survivorship, 10 yrs. FU & $99 \%$ & $95.6 \%$ & $95.4 \%$ \\
Survivorship, 20 yrs. FU & $(95 \% \text { CI; } 97-100 \%)^{28}$ & $(95 \% \text { CI; } 90.1-98.3 \%)^{69}$ & $(95 \% \text { CI; } 85.8-99.8 \%)^{70}$ \\
& $84.4 \%$ & $81.8 \%$ & $84 \%$ \\
\hline
\end{tabular}

\# - up to 2 years of follow-up ${ }^{72}$; ALVAL - aseptic lymphocytic vasculitis-associated lesions; FU - follow-up; * -22 y. survivorship of Lubinus SP II for all diagnoses and all reasons for revisions (Swedish Hip Arthroplasty Report 2008); NA - not available

Table 4. The incidence of squeaking (from the lowest to the highest incidence).

\begin{tabular}{|c|c|c|c|c|c|c|c|c|c|c|}
\hline 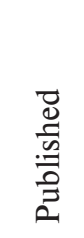 & 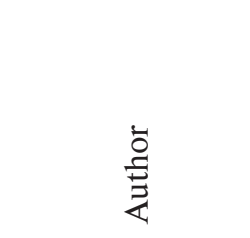 & 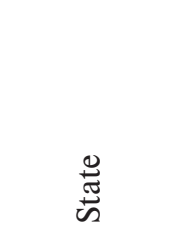 & 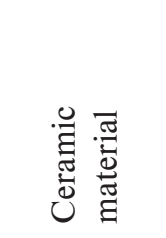 & 兽 & 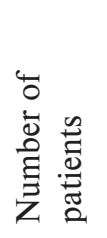 & 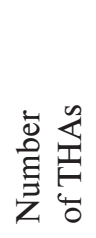 & 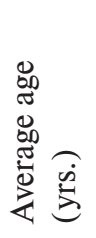 & 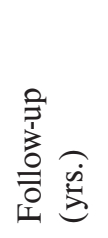 & 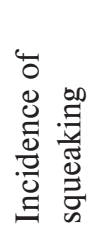 & 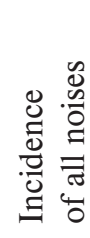 \\
\hline 2010 & Park et al ${ }^{61}$ & South Korea & NA & 1999-2002 & 90 & 102 & 39 & 9.6 & $0 \%$ & NA \\
\hline 2011 & Sugano et al. ${ }^{63}$ & Japan & Biolox forte & 1996-1998 & 87 & 100 & 56 & 14 & $0 \%$ & $0.01 \%$ \\
\hline 2007 & Lusty et $\mathrm{al}^{73}$ & Australia & Biolox forte & 1997-1999 & 283 & 301 & 58 & 7.6 & $0.3 \%$ & NA \\
\hline 2008 & Capello et al. ${ }^{74}$ & USA & Biolox forte & 1996-1998 & 452 & 475 & NA & 8.3 & $0.8 \%$ & NA \\
\hline 2011 & Mesko et al. ${ }^{62}$ & USA & NA & $1996-2000$ & 848 & 930 & 51.3 & 10 & $0.97 \%$ & $2.5 \%$ \\
\hline 2011 & D'Antonio et al. ${ }^{26}$ & USA & NA & 1996 & NA & 144 & 53.1 & 10.3 & $1.4 \%$ & NA \\
\hline 2011 & Schroder et al. ${ }^{75}$ & USA & NA & 2003-2006 & 317 & 375 & 54 & 3.0 & $1.9 \%$ & $11.0 \%$ \\
\hline 2011 & Cogan et al. ${ }^{76}$ & France & NA & 2003-2004 & 238 & 284 & 52.4 & NA & $2.6 \%$ & $10.6 \%$ \\
\hline 2010 & Restrepo et al. ${ }^{40}$ & USA & NA & 1998-2004 & 266 & 304 & 45.5 & NA & $2.7 \%$ & NA \\
\hline 2011 & Sexton et al. ${ }^{37}$ & Australia & NA & $1997-2008$ & NA & 2406 & NA & 9.4 & $3.1 \%$ & NA \\
\hline 2009 & Greene et al. ${ }^{77}$ & USA & NA & 2003-2005 & 97 & 103 & 52.6 & 4.2 & $4.9 \%$ & NA \\
\hline 2011 & Chevillotte et al. ${ }^{59}$ & France & Biolox forte & $1999-2000$ & 92 & 100 & 59 & 9 & $5.4 \%$ & NA \\
\hline 2009 & Jarrett et al. ${ }^{78}$ & USA & NA & 2003-2005 & 143 & 159 & 52 & 1.8 & $10.7 \%$ & $32.8 \%$ \\
\hline
\end{tabular}

NA - not available 
several studies demonstrated periprosthetic osteolysis even in patients with current COC THA (ref. ${ }^{19-20}$ ). The reason may lie in the multifactorial origin of osteolysis and aseptic loosening when particle related parameters play an important role but not the only pathway inducing these entities ${ }^{21}$. In addition, ceramic bearing surfaces are not the only source of prosthetic particles. In support of this is a histological study of pseudomembranes from loosened alumina cups that suggested that this "unexpected" osteolysis was probably due to metal or cement debris rather than alumina particles ${ }^{2}$. Thus, in terms of biological activity of ceramic particles, the advantages clearly outweigh the disadvantages.

\section{Clinical evidence for ceramic-on-ceramic THA}

Assuming that $\mathrm{COC}$ bearings offer the lowest wear rates and that ceramic particles induce minimal adverse biological activity, do these facts result in overall improvement in survivorship of THA?

Recent systematic reviews on survivorship of hard-onhard bearings in THA revealed variable implant longevity and rates of complications in earlier studies (survival rates of $73 \%$ to $100 \%$ at mean follow up ranging from 31 to 240 months) (ref. ${ }^{22}$ ). Early generations of ceramic-on-ceramic implants were characterized by high failure rates as a result of both component fracture and loosening of the monolithic acetabular component. However, in a recent retrospective study, Petsatodis et al. reported a survivorship of $84.4 \%$ of cementless alumina COC prostheses at 20 years follow-up ${ }^{23}$. Others have reported significant differences in survivorship of COC bearings depending on the type of prosthesis and its fixation, especially with respect to cementless and cemented cups ${ }^{2425}$. Therefore, the survivorship and rate of complications of ceramic bearing surfaces depend not only on the period of implantation (and therefore the generation of ceramic material), but also on other important factors e.g. design of the prosthesis, surgical technique and the method of femoral and acetabular fixation ${ }^{2}$.

The new generations of ceramic implants suggest more promising outcomes (Table 2), especially in young and active patients, with survivorship rates (free of revision) between $92 \%$ and $99 \%$ at ten years of follow-up ${ }^{26-30}$. However, these data are comparable but not better than the best outcomes for both metal-on-metal and metal/ceramic-onpolyethylene articulations (Table 2). In addition, the number of studies and length of follow-up for COC bearings are still insufficient compared to ceramic/metal-on-polyethylene THAs. Finally, the strength of evidence might be further compromised by methodological weaknesses as was reported for other clinical research in orthopaedics ${ }^{31}$.

As a result the conclusion is that use of highly wear resistant bearing surfaces does not automatically guarantee longer survivorship than the best non-COC THAs. The reason lies at least partially in the occurrence of other unrelated complications (e.g. deep sepsis, instability, periprosthetic fracture etc.) that require revision surgery and that are not prevented by simple choice of bearing surface (Table 3). Even aseptic loosening cannot be completely resolved using one specific bearing surface because of its multifactorial etiology $y^{32}$. On the other hand, the rate of osteolysis was diminished as a direct consequence of using ceramic bearings. Taken together, combining the best design of THA with COC bearings might improve the long-term outcomes. However, this remains to be demonstrated in well-conducted multicentre studies and/or arthroplasty registries data.

\section{DISADVANTAGES OF COC BEARINGS IN THA}

\section{Ceramic head and liner fractures}

Ceramic head and liner fractures are associated with massive metallosis and exposure of the local tissues to particles of titanium or cobalt-chromium alloy from the metallic components (Fig. 2). Earlier generations of alumina ceramic heads had a reported risk for fracture between $0.26 \%$ and $13.4 \%$, however for newer implants (Biolox Forte) the reported fracture rate is much lower at 0.004 to $0.015 \%$ (ref. ${ }^{33}$ ). Representative data for Biolox Delta are not currently available.

The risk of ceramic liner fracture in new generation ceramic materials has been reported to be between $0 \%$ and $5.3 \%$, with a higher incidence among sandwich-type
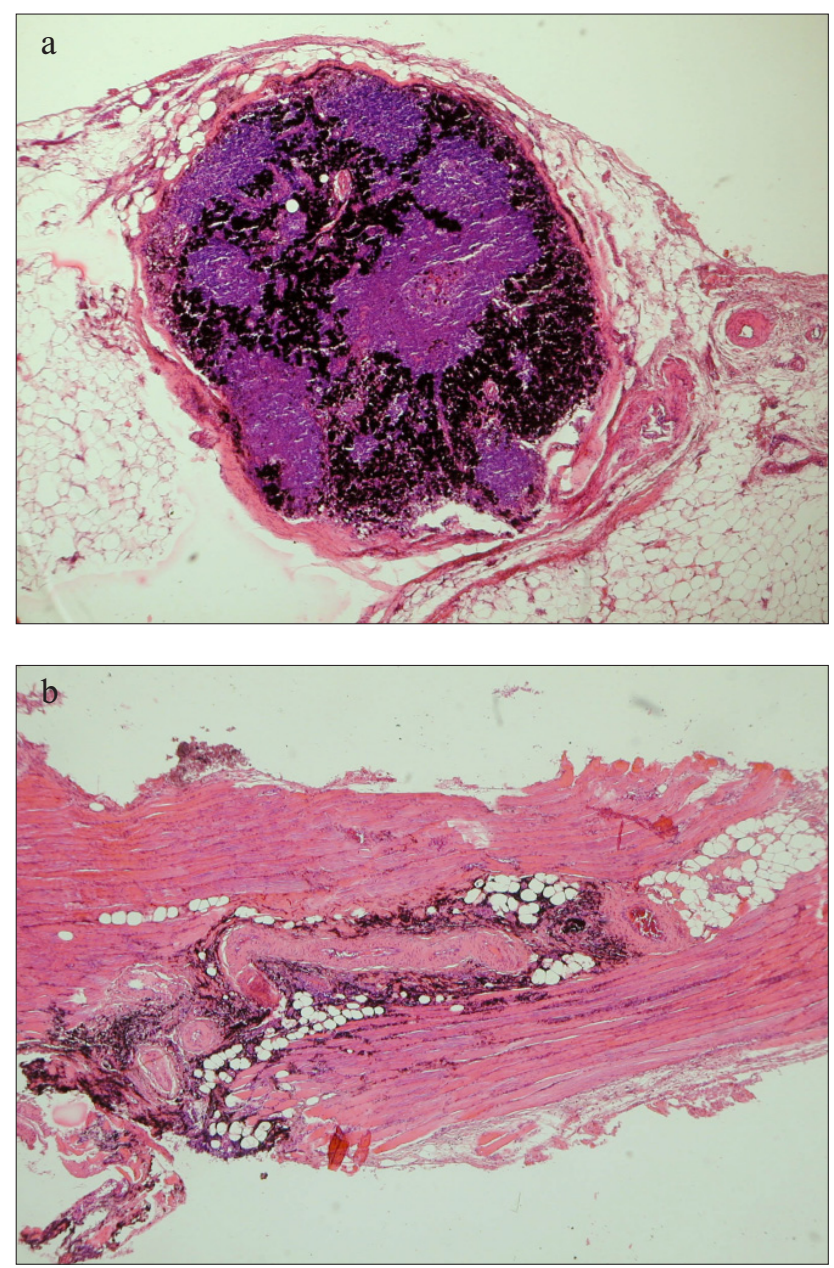

Fig. 2. Lymph node (a) and muscles (b) retrieved from surrounding of the catastrophically failed THA with large islands of metallic material (courtesy of VlastaTicha, MD, PhD, H\&E stain 40x). 
ceramic cups than 1-piece components. Szymanski et al. who reported $5.3 \%$ (7/132) of ceramic liner fractures (sandwich type implant) at a mean 32 months after the surgery also revealed clinical risk factors for fracture ${ }^{34}$. These included excessive weight, advanced age, dislocation, prosthetic impingement, and increased postoperative hip offset. In an FDA multicenter study, new composite ceramic materials (Biolox Delta alumina-on-alumina ceramic; one-piece component) exhibited no ceramic fracture within 3 years of follow-up ${ }^{35}$. However, these materials have a relatively short clinical history, so further monitoring is necessary.

\section{Squeaking}

Another concern remains squeaking of ceramic bearings. This potentially affects the patient's quality of life and survivorship of the implant due to revision of the squeaky hip. Noises emanating from ceramic bearings (usually clicking and squeaking) have been reported with rates that vary from $0 \%$ to $33 \%$ (Table 4 ).

Currently there are several theories on the origin of squeaking but the exact mechanism is still unclear, and is likely multifactorial. Some authors reported that squeaky hips are associated with younger active, heavier, and taller patients ${ }^{36-37}$. Parvizi et al. revealed an association with a particular prosthetic design that enabled neck impingement on the metallic rim of the cup ${ }^{38,39}$. Similarly, Restrepo et al. found a clear relationship between the prevalence of squeaking and the type of femoral component implanted ${ }^{40}$. Alternatively, there are studies that did not report any squeaky hips even after 10 years of follow-up (Table 4). Other explanations for COC squeaking include localized "striped" wear, changes of fluid film lubrication conditions and femoral head microseparation ${ }^{41-42}$. As a ceramic head passes over the wear stripe, it could generate a vibration and the metallic parts (femoral stem and acetabular shell) amplify this vibration by resonating, resulting in an audible sound. This explanation is consistent with the fact that COC squeaking does not occur until an average of fourteen to eighteen months after surgery. Finally, squeaking could be generated by the rolling/sliding motion of the femoral head inside the liner in the current generation of COC THAs ( ref. $^{43}$ ). Manufacturers have introduced acetabular shells with different liner materials that are interchangeable, possibly leading to a diameter mismatch in some cases that allows a rolling/sliding mechanism. Regardless of which theory is plausible, noisy hips can occur in up to $33 \%$ of hips with COC bearings; fortunately clinically the problem is often minor in the majority of patients and revision surgery is indicated only occasionally.

\section{Damage of the ceramic rim}

Direct contact between the neck of the stem and the rim of the ceramic liner during range of motion can result in rim damage. Ceramic fragments can then impose themselves between the ceramic surfaces contributing to accelerated wear. Under some circumstances forceful impingement can even result in dislocation of THA. Stafford et al. revised 6 hips with COC THAs; three of which were revised for impingement-related complications including recurrent dislocation ${ }^{44}$.

\section{Concerns related to revision of ceramic-on-ceramic THA}

One important clinical question is how to identify impending catastrophic failure of COC THA because it can occur suddenly without prior symptoms. In addition, the majority of patients with current COC THA will experience asymptomatic ongoing generation of wear debris and low risk of head or liner fracture. Toni et al. recommended performing an X-ray/CT examination in patients with noisy COC THA to distinguish between snapping hips and hips with macro-damaged bearing surfaces ${ }^{45}$. If the examination is negative then the authors recommend joint fluid aspiration to detect ceramic particles due to minor surface damage.

Another problem is the stable cup with a one-piece ceramic liner because it may be difficult to remove the ceramic liner from the metallic cup. The removal of a ceramic liner from the shell can be accomplished by a strong perpendicular impact to the rim of the shell, which might disrupt the press fit forces of the conical liner (personal communication with Karl Knahr). The inner surface of the shell must not be damaged during this impact to avoid the necessity of removal of the damaged shell. A special suction cup instrument has been developed to facilitate removal of ceramic liner out of the metal shell without damaging the metal. However, it is ineffective in firmly fixed liner.

Another important question relates to whether a new ceramic head should be implanted on a non-revised stem neck (trunion) after removal of the previous ceramic head. Potential damaged areas of the taper by forceful removal of the previous head may later serve as stress risers (Fig. 3) that can initiate and propagate a crack that ultimately leads to a fracture of the newly implanted head. When a metallic ball is implanted to replace a fractured ceramic head, care must be taken to remove all ceramic particles from the joint cavity because alumina particles remaining in the surrounding tissues could cause third body wear of the new metallic ball. In this situation, the ceramic par-

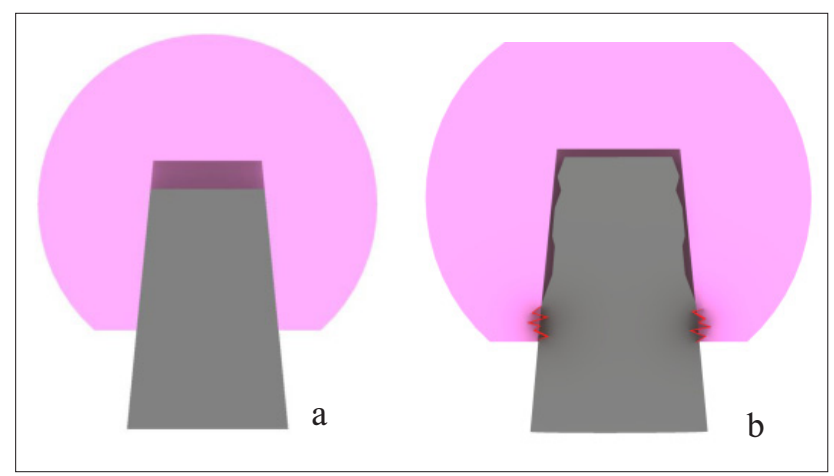

Fig. 3. Trunk of the stem can be damaged after forceful removal of the original head which could deform neck surface of the stem; these deformations could induce places of increased strains and stresses in conjunction with a new ceramic head; original situation after index surgery (a); placement of a new ceramic head on damaged neck of the stem (b) 
ticles, which are harder than metal, might damage a metal head in a short time. This is why some specialists advise against the use of a metal head in the scenario of revision due to a fractured ceramic head/liner ${ }^{46}$. Accordingly, only revision to $\mathrm{COC}$ or ceramic-on-polyethylene is recommended in this case. A special ceramic revision head system that consists of toughened dispersion ceramic ball along with titanium sleeve has been developed which allows the surgeon to retain the stem and use the original trunion (e.g. BIOLOX ${ }^{\circledR}$ OPTION; CeramTec, Germany). If the above-mentioned sleeve is not used, it is strongly recommended to exclude the possibility that the retained stem taper is damaged by close gross visual inspection ${ }^{47}$.

\section{CONCLUSION}

The newest alumina/composite ceramic bearing surfaces have only negligible risk for fracture of the head and liner, and exhibit very low wear rates. The most recent tenyear follow-up studies have demonstrated comparable survivorship with current ceramic/metal-on-polyethylene and even metal-on-metal bearing couples. The most important current concerns about $\mathrm{COC}$ bearings are squeaking, and component impingement and micro-separation, increasing the risk of surface damage and premature prosthetic failure. Risk for fracture of ceramic sandwich-type liners also remains a subject of concern. From the foregoing, the advantages and disadvantages of current COC THA should be carefully considered in younger, more active patients.

\section{ACKNOWLEDGEMENT}

This study was supported by Internal Grant Agency Ministry of Health, Czech Republic (NT/11049-5).

\section{CONFLICT OF INTEREST STATEMENT}

Author's conflict of interest disclosure: The authors stated that there are no conflicts of interest regarding the publication of this article.

\section{REFERENCES}

1. Gallo J, Kaminek P, Ticha V, Rihakova P, Ditmar R. Particle disease. A comprehensive theory of periprosthetic osteolysis: a review. Biomed Pap Med Fac Univ Palacky Olomouc Czech Repub 2002;146(2):21-8.

2. Hannouche D, Zaoui A, Zadegan F, Sedel L, Nizard R. Thirty years of experience with alumina-on-alumina bearings in total hip arthroplasty. Int Orthop 2011;35(2):207-13.

3. Kurtz SM, Ong, K. Contemporary total hip arthroplasty: Hard-onhard bearings and highly crosslinked UHMWPE. In: Kurtz SM, editor. UHMWPE Biomaterials Handbook. 2nd ed. Burlington, MA, USA: Academic Press (Elsevier);2009. p.55-79.

4. Rainforth WM, Ma L. A study of Biolox (R) delta subject to water lubricated reciprocating wear. Tribol Int 2010;43(10):1872-81.

5. Williams S, Schepers A, Isaac G, Hardaker C, Ingham E, van der Jagt D, Breckon A, Fisher J. The 2007 Otto Aufranc Award. Ceramic-on- metal hip arthroplasties: a comparative in vitro and in vivo study. Clin Orthop Relat Res 2007;465:23-32.

6. Lusty PJ, Watson A, Tuke MA, Walter WL, Walter WK, Zicat B. Wear and acetabular component orientation in third generation alumina-onalumina ceramic bearings: an analysis of 33 retrievals. J Bone Joint Surg Br 2007;89(9):1158-64.

7. Nevelos J, Ingham E, Doyle C, Streicher R, Nevelos A, Walter W, Fisher J. Microseparation of the centers of alumina-alumina artificial hip joints during simulator testing produces clinically relevant wear rates and patterns. J Arthroplasty 2000;15(6):793-5.

8. Affatato S, Traina F, Toni A. Microseparation and stripe wear in alumina-on-alumina hip implants. Int J Artif Organs 2011;34(6):506-12.

9. Tipper JL, Hatton A, Nevelos JE, Ingham E, Doyle C, Streicher R, Nevelos AB, Fisher J. Alumina-alumina artificial hip joints. Part II: characterisation of the wear debris from in vitro hip joint simulations. Biomaterials 2002;23(16):3441-8.

10. Fisher J, Jin Z, Tipper J, Stone M, Ingham E. Tribology of alternative bearings. Clin Orthop Relat Res 2006;453:25-34.

11. Catelas I, Jacobs JJ. Biologic activity of wear particles. Instr Course Lect 2010;59:3-16.

12. Fisher J, Bell J, Barbour PS, Tipper JL, Matthews JB, Besong AA, Stone $\mathrm{MH}$, Ingham $\mathrm{E}$. A novel method for the prediction of functional biological activity of polyethylene wear debris. Proc Inst Mech Eng H 2001;215(2):127-32.

13. Hannouche D, Hamadouche M, Nizard R, Bizot P, Meunier A, Sedel L. Ceramics in total hip replacement. Clin Orthop Relat Res 2005;430:62-71.

14. Catelas I, Huk OL, Petit A, Zukor DJ, Marchand R, Yahia L. Flow cytometric analysis of macrophage response to ceramic and polyethylene particles: effects of size, concentration, and composition. J Biomed Mater Res 1998;41(4):600-7.

15. Kubo T, Sawada K, Hirakawa K, Shimizu C, Takamatsu T, Hirasawa Y. Histiocyte reaction in rabbit femurs to UHMWPE, metal, and ceramic particles in different sizes. J Biomed Mater Res 1999;45(4):363-9.

16. Bos I, Willmann G. Morphologic characteristics of periprosthetic tissues from hip prostheses with ceramic-ceramic couples: a comparative histologic investigation of 18 revision and 30 autopsy cases. Acta Orthop Scand 2001;72(4):335-42.

17. Bos I. Tissue reactions around loosened hip joint endoprostheses. A histological study of secondary capsules and interface membranes. Orthopade 2001;30(11):881-9.

18. Catelas I, Petit A, Zukor DJ, Marchand R, Yahia L, Huk OL. Induction of macrophage apoptosis by ceramic and polyethylene particles in vitro. Biomaterials 1999;20(7):625-30.

19. Park YS, Hwang SK, Choy WS, Kim YS, Moon YW, Lim SJ. Ceramic failure after total hip arthroplasty with an alumina-on-alumina bearing. J Bone Joint Surg Am 2006;88(4):780-7.

20. Kurtz SM, Gawel HA, Patel JD. History and systematic review of wear and osteolysis outcomes for first-generation highly crosslinked polyethylene. Clin Orthop Relat Res 2011;469(8):2262-77.

21. Sundfeldt M, Carlsson LV, Johansson CB, Thomsen P, Gretzer C. Aseptic loosening, not only a question of wear: a review of different theories. Acta Orthop 2006;77(2):177-97.

22. Zywiel MG, Sayeed SA, Johnson AJ, Schmalzried TP, Mont MA. Survival of hard-on-hard bearings in total hip arthroplasty: a systematic review. Clin Orthop Relat Res 2011;469(6):1536-46.

23. Petsatodis GE, Papadopoulos PP, Papavasiliou KA, Hatzokos IG, Agathangelidis FG, Christodoulou AG. Primary cementless total hip arthroplasty with an alumina ceramic-on-ceramic bearing: results after a minimum of twenty years of follow-up. J Bone Joint Surg Am 2010;92(3):639-44.

24. Iwakiri K, Iwaki H, Minoda Y, Ohashi H, Takaoka K. Alumina inlay failure in cemented polyethylene-backed total hip arthroplasty. Clin Orthop Relat Res 2008;466(5):1186-92.

25. Finkbone PR, Severson EP, Cabanela ME, Trousdale RT. Ceramic-OnCeramic Total Hip Arthroplasty in Patients Younger Than 20 Years. J Arthroplasty 2012;27(2):213-9.

26. D'Antonio JA, Capello WN, Naughton M. Ceramic Bearings for Total Hip Arthroplasty Have High Survivorship at 10 Years. Clin Orthop Relat Res 2012;470(2):373-81.

27. Boyer $P$, Huten $D$, Loriaut $P$, Lestrat $V$, Jeanrot $C$, Massin $P$. Is aluminaon-alumina ceramic bearings total hip replacement the right choice in patients younger than 50 years of age? A 7- to 15-year follow-up study. Orthop Traumatol Surg Res 2010;96(6):616-22. 
28. Lee YK, Ha YC, Yoo JJ, Koo KH, Yoon KS, Kim HJ. Alumina-on-alumina total hip arthroplasty: a concise follow-up, at a minimum of ten years, of a previous report. J Bone Joint Surg Am 2010;92(8):1715-9.

29. Kress AM, Schmidt R, Holzwarth U, Forst R, Mueller LA. Excellent results with cementless total hip arthroplasty and alumina-on-alumina pairing: minimum ten-year follow-up. Int Orthop 2011;35(2):195200.

30. Jeffers JR, Walter WL. Ceramic-on-ceramic bearings in hip arthroplasty: state of the art and the future. J Bone Joint Surg Br 2012;94(6):735-45. Review.

31. van Oldenrijk J, Sierevelt IN, Schafroth MU, Poolman RW. Design considerations in implant-related randomized trials. J Long Term Eff Med Implants 2007;17(2):153-63.

32. Porat M, Parvizi J, Sharkey PF, Berend KR, Lombardi AV, Jr., Barrack RL. Causes of Failure of Ceramic-on-Ceramic and Metal-on-Meta Hip Arthroplasties. Clin Orthop Relat Res 2012;470(2):382-7.

33. Huet R, Sakona A, Kurtz SM. Strength and reliability of alumina ceramic femoral heads: Review of design, testing, and retrieval analysis. J Mech Behav Biomed Mater 2011;4(3):476-83.

34. Szymanski C, Gueriot S, Boniface O, Deladerriere JY, Luneau S, Maynou C. Sandwich type ceramic liner fracture rate with the Atlas III socket: A study of 144 primary total hip replacements at a mean 74months' follow-up. Orthop Traumatol Surg Res 2011;97(5):494500 .

35. Hamilton WG, McAuley JP, Dennis DA, Murphy JA, Blumenfeld TJ, Politi J. THA with Delta ceramic on ceramic: results of a multicenter investigational device exemption trial. Clin Orthop Relat Res 2010;468(2):358-66.

36. Walter WL, Waters TS, Gillies M, Donohoo S, Kurtz SM, Ranawat AS, Hozack WJ, Tuke MA. Squeaking hips. J Bone Joint Surg Am 2008;90 Suppl 4:102-11.

37. Sexton SA, Yeung E, Jackson MP, Rajaratnam S, Martell JM, Walter WL, Zicat BA, Walter WK. The role of patient factors and implant position in squeaking of ceramic-on-ceramic total hip replacements. J Bone Joint Surg Br 2011;93(4):439-42.

38. Parvizi J, Adeli B, Wong JC, Restrepo C, Rothman RH. A squeaky reputation: the problem may be design-dependent. Clin Orthop Relat Res 2011;469(6):1598-605.

39. Stanat SJ, Capozzi JD. Squeaking in third- and fourth-generation ceramic-on-ceramic total hip arthroplasty: meta-analysis and systematic review. J Arthroplasty 2012;27(3):445-53. Epub 2011 Jun 14. Review.

40. Restrepo C, Post ZD, Kai B, Hozack WJ. The effect of stem design on the prevalence of squeaking following ceramic-on-ceramic bearing total hip arthroplasty. J Bone Joint Surg Am 2010;92(3):550-7.

41. Taylor S, Manley MT, Sutton K. The role of stripe wear in causing acoustic emissions from alumina ceramic-on-ceramic bearings. J Arthroplasty 2007;22(7 Suppl 3):47-51.

42. Glaser D, Komistek RD, Cates HE, Mahfouz MR. Clicking and squeaking: in vivo correlation of sound and separation for different bearing surfaces. J Bone Joint Surg Am 2008;90 Suppl 4:112-20.

43. Currier JH, Anderson DE, Van Citters DW. A proposed mechanism for squeaking of ceramic-on-ceramic hips. Wear 2010;269(11-12):782-9.

44. Stafford GH, Islam SU, Witt JD. Early to mid-term results of ceramicon-ceramic total hip replacement: analysis of bearing-surface-related complications. J Bone Joint Surg Br 2011;93(8):1017-20.

45. Toni A, Traina F, Stea S, Sudanese A, Visentin M, Bordini B, Squarzoni S. Early diagnosis of ceramic liner fracture. Guidelines based on a twelve-year clinical experience. J Bone Joint Surg Am 2006;88 Suppl 4:55-63.

46. Pospischill M, Knahr K. Strategies for head and inlay exchange in revision hip arthroplasty. Int Orthop 2011;35(2):261-5.

47. Hannouche D, Delambre J, Zadegan F, Sedel L, Nizard R. Is there a risk in placing a ceramic head on a previously implanted trunion? Clin Orthop Relat Res 2010;468(12):3322-7.

48. Milosev I, Trebse R, Kovac S, Cor A, Pisot V. Survivorship and retrieval analysis of Sikomet metal-on-metal total hip replacements at a mean of seven years. J Bone Joint Surg Am 2006;88(6):1173-82.

49. Neumann DR, Thaler C, Hitzl W, Huber M, Hofstadter T, Dorn U. Longterm results of a contemporary metal-on-metal total hip arthroplasty: a 10-year follow-up study. J Arthroplasty 2010;25(5):700-8.

50. Migaud H, Putman S, Krantz N, Vasseur L, Girard J. Cementless metal-on-metal versus ceramic-on-polyethylene hip arthroplasty in patients less than fifty years of age: a comparative study with twelve to fourteen-year follow-up. J Bone Joint Surg Am 2011;93 Suppl 2:137-42.

51. Neuerburg C, Impellizzeri F, Goldhahn J, Frey P, Naal FD, von Knoch M, Leunig M, von Knoch F. Survivorship of second-generation metalon-metal primary total hip replacement. Arch Orthop Trauma Surg 2012;132(4):527-33.

52. Delaunay CP, Bonnomet F, Clavert P, Laffargue $P$, Migaud H. THA using metal-on-metal articulation in active patients younger than 50 years. Clin Orthop Relat Res 2008;466(2):340-6.

53. Kim YH, Kim JS, Park JW, Joo JH. Comparison of total hip replacement with and without cement in patients younger than 50 years of age: the results at 18 years. J Bone Joint Surg Br 2011;93(4):449-55.

54. Garavaglia G, Lubbeke A, Barea C, Roussos C, Peter R, Hoffmeyer $P$. Ten-year results with the Morscher press-fit cup: an uncemented, non-modular, porous-coated cup inserted without screws. Int Orthop 2011;35(7):957-63.

55. Grobler GP, Learmonth ID, Bernstein BP, Dower BJ. Ten-year results of a press-fit, porous-coated acetabular component. J Bone Joint Surg Br 2005;87(6):786-9.

56. Zweymuller KA, SteindI M, Schwarzinger U. Good stability and minimal osteolysis with a biconical threaded cup at 10 years. Clin Orthop Relat Res 2007;463:128-37.

57. Epinette JA, Manley MT, D'Antonio JA, Edidin AA, Capello WN. A 10year minimum follow-up of hydroxyapatite-coated threaded cups: clinical, radiographic and survivorship analyses with comparison to the literature. J Arthroplasty 2003;18(2):140-8.

58. Wroblewski BM, Siney PD, Fleming PA. Charnley low-friction arthroplasty: survival patterns to 38 years. J Bone Joint Surg $\mathrm{Br}$ 2007;89(8):1015-8.

59. Chevillotte C, Pibarot V, Carret JP, Bejui-Hugues J, Guyen O. Nine years follow-up of 100 ceramic-on-ceramic total hip arthroplasty. Int Orthop 2011;35(11):1599-604.

60. Murphy SB, EckerTM, Tannast M. Two- to 9-year clinical results of alumina ceramic-on-ceramic THA. Clin Orthop Relat Res 2006;453:97102.

61. Park YS, Park SJ, Lim SJ. Ten-year results after cementless THA with a sandwich-type alumina ceramic bearing. Orthopedics 2010;33(11):796.

62. Mesko JW, D'Antonio JA, Capello WN, Bierbaum BE, Naughton M. Ceramic-on-ceramic hip outcome at a 5- to 10-year interval: has it lived up to its expectations? J Arthroplasty 2011;26(2):172-7.

63. Sugano N, Takao M, Sakai T, Nishii T, Miki H, Ohzono K. Eleven- to 14-year Follow-up Results of Cementless Total Hip Arthroplasty Using a Third-generation Alumina Ceramic-on-ceramic Bearing. J Arthroplasty 2012;27(5):736-41.

64. Amanatullah DF, Landa J, Strauss EJ, Garino JP, Kim SH, Di Cesare PE. Comparison of surgical outcomes and implant wear between ceramic-ceramic and ceramic-polyethylene articulations in total hip arthroplasty. J Arthroplasty 2011;26(6 Suppl):72-7.

65. Paleochorlidis IS, Badras LS, Skretas EF, Georgaklis VA, Karachalios TS, Malizos KN. Clinical outcome study and radiological findings of Zweymuller metal on metal total hip arthroplasty. a follow-up of 6 to 15 years. Hip Int 2009;19(4):301-8.

66. Santavirta S, Bohler M, Harris WH, Konttinen YT, Lappalainen R, Muratoglu O, Rieker C, Salzer M. Alternative materials to improve total hip replacement tribology. Acta Orthop Scand 2003;74(4):3808.

67. Richards L, Brown C, Stone MH, Fisher J, Ingham E, Tipper JL. Identification of nanometre-sized ultra-high molecular weight polyethylene wear particles in samples retrieved in vivo. J Bone Joint Surg Br 2008;90(8):1106-13.

68. Catelas I, Wimmer MA. New insights into wear and biological effects of metal-on-metal bearings. J Bone Joint Surg Am 2011;93 Suppl 2:76-83.

69. Pieringer $H$, Auersperg V, Bohler N. Long-term results of the cementless ALLOCLASSIC hip arthroplasty system using a $28-\mathrm{mm}$ ceramic head: with a retrospective comparison to a $32-\mathrm{mm}$ head. J Arthroplasty 2006;21(7):967-74.

70. Shetty V, Shitole B, Shetty G, Thakur H, Bhandari M. Optimal bearing surfaces for total hip replacement in the young patient: a metaanalysis. Int Orthop 2011;35:1281-7.

71. Brown SR, Davies WA, DeHeer DH, Swanson AB. Long-term survival of McKee-Farrar total hip prostheses. Clin Orthop Relat Res 2002;402:157-63. 
72. Bozic KJ, Ong K, Lau E, Kurtz SM, Vail TP, Rubash HE, Berry DJ. Risk of complication and revision total hip arthroplasty among Medicare patients with different bearing surfaces. Clin Orthop Relat Res 2010;468(9):2357-62.

73. Lusty PJ, Tai CC, Sew-Hoy RP, Walter WL, Walter WK, Zicat BA. Thirdgeneration alumina-on-alumina ceramic bearings in cementless total hip arthroplasty. J Bone Joint Surg Am 2007;89(12):2676-83.

74. Capello WN, D'Antonio JA, Feinberg JR, Manley MT, Naughton M. Ceramic-on-ceramic total hip arthroplasty: update. J Arthroplasty 2008;23(7 Suppl):39-43.
75. Schroder D, Bornstein L, Bostrom MP, Nestor BJ, Padgett DE, Westrich $\mathrm{GH}$. Ceramic-on-ceramic total hip arthroplasty: incidence of instability and noise. Clin Orthop Relat Res 2011;469(2):437-42.

76. Cogan A, Nizard R, Sedel L. Occurrence of noise in alumina-onalumina total hip arthroplasty. A survey on 284 consecutive hips. Orthop Traumatol Surg Res 2011;97(2):206-10.

77. Greene JW, Malkani AL, Kolisek FR, Jessup NM, Baker DL. Ceramic-onceramic total hip arthroplasty. J Arthroplasty 2009;24(6 Suppl):15-8.

78. Jarrett CA, Ranawat AS, Bruzzone M, Blum YC, Rodriguez JA, Ranawat CS. The squeaking hip: a phenomenon of ceramic-on-ceramic total hip arthroplasty. J Bone Joint Surg Am 2009;91(6):1344-9. 